\title{
Journal of Political Science Education Editors' Report
}

\author{
Victor Asal, University at Albany, State University of New York, Editor in Chief \\ Mitchell Brown, Auburn University, Coeditor \\ Mark L. Johnson, Minnesota State Community and Technical College, Coeditor \\ Shane Nordyke, University of South Dakota, Coeditor \\ Joseph W. Roberts, Roger Williams University, Coeditor \\ J. Cherie Strachan, Central Michigan University, Coeditor \\ Mirren Galway, University at Albany, State University of New York, Managing Editor \\ Olivia Vecchio, University at Albany, State University of New York, Managing Editor \\ Margaret Bidwell, Roger Williams University, Editorial Assistant \\ Tatevik Khachatryan, Roger Williams University, Editorial Assistant
}

T he editorial team for the Journal of Political Science Education has now been running the journal for the last three years with support from APSA and specifically from Jon Gurstelle, Director of Publications for APSA. In our third year working on the journal the process has gone well and we have a good team of managing editors and editorial assistants at the University at Albany and Roger Williams University.

\section{HIGHLIGHTS FROM OUR 3RD YEAR}

Now ending our third year as an APSAwide journal, we have seen submissions go up since we took over the journal (though down a bit from last year). We are getting a good number of submissions from authors for all four sections of the journal: Scholarship of Teaching and Learning (SoTL); Political Science Instruction, Teaching Tools, \& Educational Resources; Reflections on Teaching and the Academy; and book reviews. In the past year, we have made progress in our effort to improve social media engagement, with our Twitter account (@JPSE_Editors) regularly tweeting about pedagogy-related issues and announcing JPSE articles as they are released. That being said, we plan to increase Twitter activity this coming year, hopefully improving on our current follower count of 300 .

Table 1

\begin{tabular}{lcc}
$\begin{array}{l}\text { Authors by Gender } \\
\text { Female }\end{array}$ & Male & Total \\
\hline $40(56 \%)$ & $32(44 \%)$ & 72 \\
\hline
\end{tabular}

Parentheses-Percentage of Total including coauthors, all original submissions
One important decision the editorial team made this year was to discontinue yearly special issues in response to lower submission numbers for these issues. Instead, we decided to invite submissions for special sections so that we would not be dependent on getting enough manuscripts to fill each of the four sections of the journal on one topic for one issue. Last year, nearly $50 \%$ of author submissions came from women. This year, $56 \%$ of the published authors in JPSE were women (see table 1). In terms of publicizing the journal, we once again hosted a "Meet the Editors" roundtable at the 2019 APSA Annual Meeting. In summary, our team has enjoyed this third year and we are looking forward to continuing to grow the journal and its outreach as an APSA-wide journal.

\section{STAFFING}

Our staff at the Journal of Political Science Education consists of six co-editors who are using a portion of their time to work as a team as well as specifically on their own section of the journal. Two student managing editors and two editorial assistants work part-time on the journal. Our current managing editors are Mirren Galway and Olivia Vecchio who will be continuing this year. Both managing editors are students at the University at Albany SUNY. Margaret Bidwell, and Tatevik Khachatryan, students at Roger Williams University, are currently serving as editorial assistants and will continue to do so this coming year.

\section{PRODUCTION AND DELIVERY}

Author Demographics

The demographic distribution of the Journal of Political Science Education authors is reported in tables 1, 2, and 3 . We should note that Taylor \& Francis does not collect other demographic data. Currently, $56 \%$ of our article authors are

Table 2

Authors by Rank

\begin{tabular}{llllllll} 
Professor & $\begin{array}{l}\text { Associate } \\
\text { Professor }\end{array}$ & $\begin{array}{l}\text { Assistant } \\
\text { Professor }\end{array}$ & Lecturer & Student & $\begin{array}{l}\text { Administration/ } \\
\text { Professional }\end{array}$ & Other & Total \\
\hline $11(15.3 \%)$ & $11(15.3 \%)$ & $20(28 \%)$ & $9(12 \%)$ & $12(17 \%)$ & $6(8 \%)$ & $3(4 \%)$ & 72
\end{tabular}

Parentheses-Percentage of Total including coauthors, all original submissions

Table 3

\begin{tabular}{|c|c|c|c|c|c|c|c|c|c|}
\hline Australia & Brazil & Canada & Germany & Hong Kong & S. Korea & Sweden & UK & US & Total \\
\hline $\begin{array}{l}1 \\
(1.3 \%)\end{array}$ & $\begin{array}{l}1 \\
(1.3 \%)\end{array}$ & $\begin{array}{l}1 \\
(1.3 \%)\end{array}$ & $\begin{array}{l}1 \\
(1.3 \%)\end{array}$ & $\begin{array}{l}1 \\
(1.3 \%)\end{array}$ & $\begin{array}{l}1 \\
(1.3 \%)\end{array}$ & $\begin{array}{l}2 \\
(2.5 \%)\end{array}$ & $\begin{array}{l}2 \\
(2.5 \%)\end{array}$ & $\begin{array}{l}68 \\
(86.2 \%)\end{array}$ & $\begin{array}{l}79 \\
(100 \%)\end{array}$ \\
\hline
\end{tabular}

Parentheses-Percentage of Total including coauthors, all original submissions 
Table 4

\section{Authors by Type of Institution}

\begin{tabular}{clllll} 
& College & Nonacademic & Private University & Public University & Total \\
\hline July-Sept 2018 & $1(5.9 \%)$ & $1(5.9 \%)$ & $2(11.8 \%)$ & $13(76.4)$ & 17 \\
\hline Oct-Dec 2018 & $2(10 \%)$ & $1(5 \%)$ & $4(20 \%)$ & $13(65 \%)$ & 20 \\
\hline Jan-March 2019 & $1(5.6 \%)$ & $0(0 \%)$ & $2(11.1 \%)$ & $15(83.3 \%)$ & 18 \\
\hline April-June 2019 & $1(5.8 \%)$ & $0(0 \%)$ & $3(17.7 \%)$ & $13(76.5 \%)$ & 17 \\
\hline Total Percentage & $5(6.9 \%)$ & $2(2.7 \%)$ & $11(15.4 \%)$ & $54(75 \%)$ & $72(100 \%)$
\end{tabular}

Parentheses-Percentage of Total including coauthors, all original submissions

Table 5

Types of Submission

\begin{tabular}{lllll}
$\begin{array}{l}\text { Scholarship of } \\
\text { Teaching and Learning }\end{array}$ & $\begin{array}{l}\text { Political Science } \\
\text { Instruction }\end{array}$ & $\begin{array}{l}\text { Books, Teaching Tools, } \\
\text { and Educational Resources }\end{array}$ & Reflections & Total \\
\hline $30(37 \%)$ & $25(31 \%)$ & $15(18.5 \%)$ & $11(13.5 \%)$ & 81
\end{tabular}

Parentheses-Percentage of Total, all original submissions

Table 6

Manuscript Decision (Original Submissions)

\begin{tabular}{llll} 
Accepted & Revise and Resubmit & Reject* & Total \\
\hline $16(21 \%)$ & $40(48 \%)$ & $25(31 \%)$ & $81(100 \%)$
\end{tabular}

* This is the percentage of all rejected manuscripts, not of all new manuscripts

Parentheses-Percentage of Total, all original submissions

Table 7

\section{Reviewer Statistics}

\begin{tabular}{ll|lll} 
Reviews Invited & Reviews Completed & No Replies & Declines & Assigned/Agreed \\
\hline 479 & $319(66 \%)$ & $42(8 \%)$ & $89(18 \%)$ & $341(71 \%)$ \\
\hline
\end{tabular}

Table 8

Average Reviewer

Turnaround Time

\begin{tabular}{ll} 
Editorial Board & Reviewers \\
\hline 26 days & 31.15 days \\
\hline
\end{tabular}

women-a $9 \%$ increase from last year. Our authors also represent different ranks, with assistant professors (28\%) accounting for more submissions than any other rank. $30.6 \%$ of articles came from tenured faculty. There was a slight decrease in international submissions this year, down from $13.1 \%$ to $12.8 \%$. However, a greater number of countries (eight) were represented in this year's submissions. Table 4 shows the distribution of authors by type of institution for accepted papers.
Content and Treatment of Manuscripts

The number of manuscripts submitted has decreased from 99 last year to 81 this year, but that this is still up dramatically from 40 in the first year of the journal. Table 5 shows the submissions of manuscripts to each of the journal's sections, while Table 6 shows the manuscript decisions. Our current rejection rate is $31 \%$, an increase of $12 \%$. Table 7 presents information on reviewer statistics. The percentage of completed reviews has decreased from $70 \%$ last year to $66 \%$ this year but remains above the percentage of the first year. Table 8 provides data on the average reviewer turnaround time. This table reflects a slight improvement in turnaround time by the editorial boardfrom 27.86 days last year to 26 this yearand slight increase in turnaround time by reviewers from 28.79 days last year to 31.15 days this year.

\section{Makeup of the Editorial Board}

Table 9 shows the gender makeup of the editorial board of JPSE. Table 10 shows the distribution of the board by type of institution, with most of the board working at public universities. Table 11 shows that most of the editorial board is from the United States, except for four international members.

\section{Publicity and Outreach}

The editors of the Journal of Political Science Education are working to increase our publicity and outreach. We are continuing to ask authors to provide a 50-word blurb and a 130-character tweet, many of which have been shared on PSNow. We plan to continue attending each Teaching and Learning and APSAwide conference, holding "Meet the Editors" tables where we can reach out to potential authors about submitting to the journal. When it is possible, members of our editorial team have organized such events at regional APSA conferences, and we plan to continue to do so.

Table 9

Ed. Board by Gender

\begin{tabular}{lcc} 
Female & Male & Total \\
\hline $12(46 \%)$ & $14(54 \%)$ & 26 \\
\hline \multicolumn{2}{l}{ Parentheses-Percentage of Total }
\end{tabular}


Table 10

Editorial Board by Type of Institution

College Nonacademic Private University Public University Total

\begin{tabular}{lllll}
\hline $2(8 \%)$ & $0(0 \%)$ & $6(23 \%)$ & $18(69 \%)$ & $26(100 \%)$
\end{tabular}

Table 11

Editorial Board by Country

\begin{tabular}{lllll} 
Belgium & Slovakia & UK & US & Total \\
\hline $1(4 \%)$ & $1(4 \%)$ & $2(8 \%)$ & $22(85 \%)$ & $26(100 \%)$ \\
\hline
\end{tabular}

Table 12

Editorial Board by Rank

\begin{tabular}{llllll} 
Professor & $\begin{array}{l}\text { Associate } \\
\text { Professor }\end{array}$ & $\begin{array}{l}\text { Assistant } \\
\text { Professor }\end{array}$ & Lecturer & $\begin{array}{l}\text { Administration/ } \\
\text { Professional }\end{array}$ & Total \\
\hline $15(57.7 \%)$ & $5(19.2 \%)$ & $3(11.6 \%)$ & $1(3.8 \%)$ & $2(7.7 \%)$ & $26(100 \%)$ \\
\hline
\end{tabular}

Parentheses-Percentage of Total including coauthors, all original submissions 